\title{
PARTHENOGENESIS IN SCORPIONS: SOME HISTORY - NEW DATA
}

\section{LOURENÇO W. R. (1)}

(1) National Museum of Natural History, Department of Systematics and Evolution, Arthropods, Arachnology Section, Paris, France.

ABSTRACT: Parthenogenesis, a rare phenomenon in Chelicerates, apart from mites, is reviewed in scorpions, notably Tityus serrulatus Lutz \& Mello from Brazil, Tityus columbianus (Thorell) from Colombia and Tityus metuendus Pocock from Peru and Brazil. Thelytokous parthenogenesis (with all-female broods) is most often observed. The only known exception to this is $T$. metuendus in which arrhenotoky (all-male broods) has been observed. In the present paper, current ideas regarding parthenogenesis in scorpions are summarized. The notion of geographic parthenogenesis ('parthénogenèse géographique'), coined by Vandel in 1928, is discussed. This rule is tentatively exemplified by a new case of parthenogenesis reported in a scorpion of the genus Tityus C. L. Koch, inhabiting 'Pico da Neblina' in Brazil / Venezuela.

KEY WORDS: scorpions, geographic parthenogenesis, review, thelytoky, arrhenotoky, deutherotoky.

CONFLICTS OF INTEREST: Conference presented in the Symposium "Reproductive Biology of Scorpions" during the $17^{\text {th }}$ International Congress of Arachnology, August 5-10, 2007, São Pedro, São Paulo State, Brazil.

\section{CORRESPONDENCE TO:}

WILSON R. LOURENÇO, Muséum National d'Histoire Naturelle, Département de Systématique et Evolution, USM 0602, Section Arthropodes (Arachnologie), CP 053, 57 rue Cuvier 75005 Paris, France: Email: arachne@mnhn.fr. 


\section{INTRODUCTION}

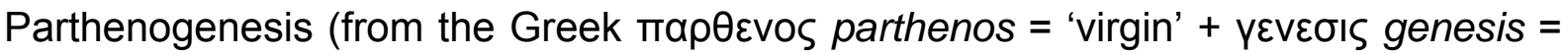
'birth') is a form of reproduction in which the ovum develops without fertilization. With the exception of mites, this phenomenon is rare among Chelicerates $(42-44,49)$. It has, however, been observed in a few species of harvestmen, spiders and scorpions $(4,9,10,14,24,53)$. Of nearly 1600 species of scorpions distributed throughout the world, pathenogenesis was demonstrated or suggested for only eleven $(26,32)$. The first of these was reported by Matthiesen (34) of the São Paulo State University (UNESP, Rio Claro), in the Brazilian species Tityus serrulatus Lutz \& Mello, 1922 (Figures 1 and 2). The other known or suggested parthenogenetic species are Tityus uruguayensis Borelli, 1901 from Uruguay and Brazil, Tityus columbianus (Thorell, 1876) from Colombia, Tityus trivittatus Kraepelin, 1898 from Argentina, Brazil and Paraguay, Tityus stigmurus (Thorell, 1876) from Brazil, Tityus metuendus Pocock, 1897 from Peru and Brazil, Ananteris coineaui Lourenço, 1982 from French Guyana, Centruroides gracilis (Latreille, 1804) from Cuba, Hottentotta hottentotta (Fabricius, 1787) from West Africa, Hottentotta caboverdensis Lourenço and Ythier, 2006 from the Cape Verde Islands, and Liocheles australasiae (Fabricius, 1775) from the South Pacific $(32,51,52,62)$ (see Figures 3 to 13). It is obvious, however, that for some of these species further investigations are yet necessary to clearly confirm parthenogenetic reproduction. Thelytokous parthenogenesis (with all-female broods) is the general trend observed among scorpions (24). The only known exception is $T$. metuendus in which arrhenotoky (all-male broods) has been observed (28).

In the present review, ideas about parthenogenesis in scorpions are summarized. The notion of geographic parthenogenesis (or 'parthénogenèse géographique') as coined by Vandel in 1928 (54) is discussed.

\section{ADVANTAGES OF SEXUAL AND PARTHENOGENETIC REPRODUCTION}

As already pointed out by Lourenço and Cuellar (27), approximately 95\% of all living species reproduce sexually. The origin of sexual reproduction is not clear, however, and it has probably evolved independently among living organisms several times. Since sexual reproduction allows genetic recombination, it should also permit the rapid incorporation of favorable mutations. Muller (41) was the first to propose that sex accelerates evolution because two favorable mutations ( $A$ and $B$ ) are more likely to arise in different individuals of the same population than in a single individual. In 
asexual species, $A B$ can only arise when two similar mutations occur simultaneously in the same individual $(37,61)$.

A somewhat similar hypothesis, attempting to explain the advantages of sexual reproduction, was formulated by Van Valen (55). The environment of any given species is comprised of two major factors, abiotic and biotic. Abiotic factors consist of physical factors such as climate, whereas the biotic constitute plants and animal species in the environment, particularly closely related forms competing with each other for limited resources such as food. Among such species, any evolutionary modifications adapting one to the environment may be detrimental to the other, but their evolution does not influence the abiotic factors. Therefore, each of the competing species must evolve constantly and rapidly in response to the modifications of the other. Otherwise, the least adaptable species will ultimately be eliminated by the selective forces of competition. This is what Van Valen (55) called 'the Red Queen effect', in an analogy from Lewis Carol's book, of 'Alice in Wonderland', in which the Red Queen said to Alice, "Here you see, it takes all the running you can do to keep in the same place." In environments such as rain forests therefore, where competition is extremely intense, sexual reproduction is not merely advantageous, but a necessity.

The Red Queen hypothesis, however, does not seem to accord with the geographic distribution of parthenogenetic animals, the majority of which occur in remote habitats isolated from their bisexual congeners. According to Cuellar (8), the major reason for the insular distribution of parthenogenetic species is the ability of single individuals to find a new colony without a member of the opposite sex. Assuming that parthenogenetic species are truly superior colonizers and have evolved in isolation away from their bisexual progenitors $(6,8)$; then, competition does not appear to have played an important role in their evolution. Aside from the potentially disruptive influence of competition on the establishment of unisexual clones, fertilization of virgin females would also eliminate unisexual lineages by disrupting all-femaleness as well as the meiotic process which regulates constancy of ploidy and the integrity of the species $(6,7)$. At least initially, therefore, parthenogenetic species must escape their bisexual counterparts in order to find new colonies. As long as they remain isolated from the bisexuals, they can circumvent extinction.

Although sexuality is the predominant mode of reproduction among all organisms, it is not entirely devoid of costs. The most common of these are meiosis and the 
production of males $(37,61)$. As stated by Mayr (38), "in parthenogenetic animals, all zygotes are egg-producing females that do not waste half of their eggs on males." Nevertheless, sexual reproduction has the long-term advantage, which is undoubtedly the reason why it has appeared several times during evolutionary history and is the principal reproductive mechanism in living organisms $(1,36,61)$. In contrast, parthenogenesis is only advantageous under special environments (8), may not be very old evolutionarily (1), and is considered to be an evolutionary blind alley $(59,60)$.

\section{GEOGRAPHIC PARTHENOGENESIS}

As previously pointed out by Cuellar (8), an enormous volume of literature has appeared on animal parthenogenesis in the last 35 years. This ranges from understanding their genetic structure, phylogenetic and systematic relationships, ploidy, mechanisms of meiosis, competitive interactions with bisexual species, modes of origin and, to a much lesser extent, their ecology and geographic patterns of distribution $(1,7,8,60)$. As a matter of fact, these last two fields remain the least understood of all the phenomena concerned with the origin of parthenogenesis.

Most research on different zoological groups has been concerned with attempting to determine whether parthenogenesis has resulted directly from hybridization, despite the fact that no one has ever produced a parthenogenetic strain through hybridization (7). The principal field of research is molecular genetics, and the principal tools are protein electrophoresis and analysis of mitochondrial DNA. Although such molecular studies have contributed extensively to the understanding of clonal inheritance, we have progressed very little ecologically since Vandel (54) first published his classical study on the geography of parthenogenetic animals almost 80 years ago.

The contribution by Vandel (54) was exceptionally important for modern workers because it established for the first time a connection between parthenogenesis and specific environments, for which Vandel coined the term 'parthénogenèse géographique.' It is known today as Vandel's 'rule of geographic parthenogenesis'. According to this rule, whenever closely related bisexual and parthenogenetic species occur in a given region, their geographical patterns tend to be different. In general, the parthenogenetic species occur in habitats that are further north or higher, colder or drier than those of their bisexual counterparts (Figure 14). Vandel (54) developed his rule when analyzing the distribution of the different races of the 
isopod Trichoniscus elisabethae. He noted that the bisexual populations occurred only in the mountains of Southern France, which are extensively forested and damp, whereas the parthenogenetic populations occupied lower and drier regions. Vandel's rule has now been widely cited by modern workers $(6,8,11,12,60)$, and numerous new examples have been added to his original list $(16,47,48,60)$.

As already emphasized by Cuellar (8), however, the exact ecological reasons for these different geographic distributions have not yet been clearly elucidated. Moreover, there is no conclusive evidence demonstrating that cold alone, aridity, or high latitudes are responsible for the differences in distribution. Parthenogenesis is also common at low latitudes as well as in tropical environments which are humid and warm. Therefore, some factors other than climate and latitude must be involved in determining its varying different geographic patterns. In discussing the distribution of Vandel's isopod Trichoniscus elisabethae, White (59) suggested that the main reason for the peripheral distribution of the parthenogenetic races might be that they have found it easier to expand their ranges merely because every individual was capable of founding a local colony of the species and there was no reproductive wastage. In proposing this explanation, White emphasized two important attributes of parthenogenetic animals: a stronger dispersal ability and a higher prolificity compared with those of bisexuals. Cuellar $(6,8)$ later suggested that parthenogenetic species can only exist in habitats that are devoid of bisexual species, first because fertilization would disrupt the perpetuation of a pure unisexual lineage and, secondly, competition would impede its expansion. Consequently, parthenogenesis should theoretically evolve in habitats where males tend to be rare, in remote or insular habitats where both sexes of a bisexual species are not likely to arrive simultaneously and, finally, in newly created habitats where high prolificity allows parthenogenetic forms to invade first, and then to outcompete bisexuals (Figures 14 and 15).

\section{SELECTED EXAMPLES OF GEOGRAPHIC PARTHENOGENESIS IN SCORPIONS} Tityus serrulatus Lutz \& Mello, 1922

In the first recorded case of parthenogenesis among scorpions (34), pregnant females of Tityus serrulatus from Brazil were collected in the field. Their all-female progeny were then raised individually, giving virgin birth to a second generation from 
four to seven months later. Matthiesen's (34) findings were confirmed some years afterwards by San Martin and Gambardella (46). Thereafter, Tityus serrulatus was considered to be an obligate parthenogenetic species. Recently, however, a possible bisexual population has been detected in the state of Minas Gerais (Figure 16), Brazil, by Lourenço and Cloudsley-Thompson (23). Tityus serrulatus may possibly have originated as a savanna-dwelling species (Figure 17), or perhaps inhabited palm trees. Today, however, it is virtually restricted to human habitations (Figure 18) and the natural savannas have been converted to agriculture and grazing. Its postulated original habitat of isolated palm trees within a vast savanna would conform with the concept of insular parthenogenesis proposed by Cuellar $(6,8)$ for the origin of parthenogenetic lizards. According to this author, the chances of colonizing remote or isolated habitats "are greater if the colonizer can reproduce without a member of the opposite sex, for it dispenses with the need to have both sexes reach the same place simultaneously." With the expansion of human communities in Western Brazil, the geographic range of $T$. serrulatus has increased considerably. Accordingly, it poses an exceptional health problem in Brazil, due not only to its innate prolificacy and rapid expansion into urban areas, but also to its great toxicity. This species possesses the most lethal venom of all the South American scorpions $(22,25,27,31)$.

Within historical times, Tityus serrulatus occupied a restricted area in the state of Minas Gerais in Brazil, but today it is widely distributed throughout the southeast and central-western regions of the country. The geographical expansion of this species has undoubtedly been related to human colonization, which began about 300 years ago from the Atlantic coastal region westward. Typically, newly erected towns are invaded within a few years after their foundation, although the surrounding natural areas are virtually devoid of this species of scorpion. The rapid expansion of $T$. serrulatus into human dwellings was recently demonstrated by its invasion of Brasilia (30). Construction of Brasilia, the capital of Brazil, was initiated in 1956 and completed during the 1970's. From 1971 to 1975, a precise inventory of the local scorpions and their densities was conducted in this region, yielding three species (17, 18): Tityus fasciolatus Pessôa, 1935, Bothriurus araguayae Vellard, 1934 and Ananteris balzani Thorell, 1891 (17, 18). Among these, T. fasciolatus represented $93 \%$ of the total population. This species is similar to $T$. serrulatus in several traits. Both average essentially the same adult size (65 versus $67 \mathrm{~mm}$ ), same brood size, 
same embryonic development (2.5-3 months) and the same age to maturity (2.0-2.5 years). However, $T$. fasciolatus is bisexual, with a sex ratio of 1 male to 3 females. The two species also differ in their type of population regulation, that of $T$. fasciolatus being density-dependent and that of $T$. serrulatus density-independent. Consequently, the populations of $T$. fasciolatus have been stable for many years (17), whereas those of $T$. serrulatus have fluctuated widely (30). Since the introduction of $T$. serrulatus into Brasilia and the adjoining of Federal District during the late 1980's and early 1990's, the populations of $T$. fasciolatus have been rapidly declining. A new inventory conducted more recently revealed that $T$. serrulatus now constitutes $70 \%$ of the scorpions in this urbanized region $(30,31)$, and is undoubtedly displacing the bisexual $T$. fasciolatus. Other cities in Brazil have been similarly invaded $(22,25,27)$.

Scorpionism is well known in Brazil and has been documented there since the end of the $19^{\text {th }}$ Century $(22,25,31)$. The first comprehensive study of the phenomenon was that of Maurano (35), whose work dealt primarily with Tityus bahiensis (Perty, 1833), the second most toxic species in South America. This species was originally described in Brazil.

Before the publication of Maurano's work, not much had appeared in the literature about scorpion problems in Brazil. This is curious because of the enormous health problem caused by scorpions there today.

The fact that Maurano's work dealt only with $T$. bahiensis, as well as that antivenom serum has been produced from this species since 1915, can probably be explained by the fact that $T$. serrulatus was not described until 1922. However, one important question can be addressed: how is it that such a common species as $T$. serrulatus, well known since the 1920's, had not been observed previously and was described rather later than the other common species? According to Magalhães (33), his laboratory in Minas Gerais received 600,000 specimens between 1922 and 1952. I have suggested (18) that $T$. serrulatus may be closely related to Tityus stigmurus (Thorell), a species (Figure 7) with both sexual and parthenogenetic populations and with a current distribution further to the north than that of $T$. serrulatus. Several other authors, however, have refused categorically to recognize the possible existence, in the past, of a southern distribution of $T$. stigmurus covering the present geographic range of $T$. serrulatus $(40,45,57)$. Others affirm that, before $1920, T$. stigmurus was a common species in the central and southern regions of Brazil in the states of Minas 
Gerais, São Paulo and Goiás, where it lived sympatrically with $T$. serrulatus $(39,56)$. During the late 1970's, I was able to discuss this personally with Jean Vellard and to examine some of the material that he collected in the late 1920's, thereby confirming his results. Tityus stigmurus was undoubtedly a common species in the state of Minas Gerais and south of Goiás, at least until the late 19th Century.

Tityus stigmurus was originally described from the state of Pernambuco in the Northeast of Brazil. This is due to the fact that such region had been prospected earlier in Brazilian history. In the recent past, about 300 years ago, the distribution of $T$. stigmurus ranged from Minas Gerais to the northeastern states of Brazil. The date at which the parthenogenetic species $T$. serrulatus appeared de novo is difficult to establish. However, if $T$. serrulatus was already present in Minas Gerais before the beginning of the 18th Century, its presence was extremely inconspicuous. At the beginning of the 18th Century, an important development was engendered by the Portuguese (especially in their search for gold) with the foundation of towns such as Curral d'El Rei and Vila Rica de Ouro Preto (15). Previously metaclimax environments suffered human impact, turning them into a disclimax situation. This favored the previously discrete parthenogenetic population of Tityus serrulatus, a much more opportunistic species than $T$. stigmurus, and enabled it to explore the newly created disclimax habitat. The expansion of human colonization toward the west and north resulted in a significant regression of the original bisexual population of $T$. stigmurus, which was gradually replaced by a population of $T$. serrulatus. As already mentioned, this species usually colonizes urban areas (cities and tows), and can easily be transported by human agency from old to new cities. Brasilia has been invaded and was colonized by $T$. serrulatus in less than 15 years (30).

\section{Tityus columbianus (Thorell, 1876)}

Parthenogenesis was first demonstrated in Tityus columbianus (Figure 4) by Lourenço (20). Although only females had been detected in this Colombian species since its description, Lourenço (20) also cited the discovery of a single male in the northern part of its range. Subsequently, a $250 \mathrm{~km}$ survey conducted throughout its entire range (Figure 19) revealed the presence of a sexual population in the northern region, with a female to male sex ratio of about 2:1. The geographic differences in reproductive effort between sexual populations of this species (from Iza - Figure 20) and parthenogenetic populations (from Mosquera - Figure 21), both in Colombia, 
were compared (29). The sexual females from Iza were significantly larger and had markedly greater relative litter masses (RLM) than had the parthenogenetic females from Mosquera (Figure 22). In both populations, litter size increased significantly with female body size. Iza receives significantly more precipitation during the critical growing season and is also significantly warmer than Mosquera. In addition, Mosquera experiences a distinct period of drought in the middle of the summer. This limits productivity to spring and autumn (for precise values see Lourenço et al. (29)). The heavier body weights and larger litters of the sexual individuals may therefore be due to environmental differences in primary productivity (29).

\section{Tityus metuendus Pocock, 1897}

Tityus metuendus (Figure 8 ) is a rainforest species distributed mainly in Western Amazonia between Brazil and Peru. In the vicinity of Manaus, Brazil (specifically in the Ducke Reserve), the populations of $T$. metuendus are strictly sexual with equal numbers of males and females (19). During field studies in the Amazonian region of Peru, near lquitos (the town of Jenaro Herrera), a single juvenile female of $T$. metuendus was collected from a palm tree (Astrocaryum chambira - Figure 23) and brought to the laboratory in Paris (13). About three months after its last molt, on October 18, 1996, this female gave birth to a brood of 21 neonates. Of these, only three (all males) survived to the adult stage (Figure 24). A detailed examination of the size and structure of the pectines of the immature specimens, which died and were preserved, revealed that the entire brood consisted of males. On September 29, 1997, the same female produced another brood of 32 . Three of these did not complete embryological development and 29 were normal. The normal ones all died a few days after the first molt. As with the previous brood, examination of the pectines revealed only males. A third all-male brood was born on April 30, 1998, bringing further evidence of the possible existence of arrhenotoky in this species. The production of three consecutive all-male broods by the same virgin female may well represent the first known case of arrhenotoky (the production of males from unfertilized eggs) in scorpions $(24,28)$, and possibly among all Arachnida other than Acari (42). No data are yet available from scorpions, as there are for other arthropod groups, such as the Hymenoptera $(7,58)$ and mites, to explain either the meiotic mechanism of arrhenotoky or its evolutionary significance (3). According to Taylor and Sauer (50), a major selective advantage of arrhenotoky compared with diploidy 
is that mothers can precisely determine the sex ratios of their offspring by controlling the fertilization of each egg. This is particularly advantageous in species with finite mating groups in which the probability is high that some clutches may contain no males (42), or in which the sex ratio may be biased in favor of females (5). Precise sex ratios have been documented in the case of several arrhenotokous species of parasitic wasps (58) which lay their eggs either in a single host or in a clumped group of hosts. In phytoseiid mites, pseudo-arrhenotoky has apparently arisen as a consequence of low mobility and a subdivided population structure. Their dominant prey form patchy infestations which are probably invaded by only a few females, leading to very small mating groups (42). Similar mating conditions may exist for $T$. metuendus, but extensive field work will be needed to explain its life history and behavior.

\section{A NEW CASE OF PARTHENOGENESIS WITH A TITYUS SPECIES FROM 'PICO DA NEBLINA' IN BRAZIL I VENEZUELA}

A few specimens, males and females, of a scorpion belonging to a new species of the genus Tityus were collected alive by a group of biologists in November 2001 January 2002 in the 'Pico da Neblina', located between Brazil and Venezuela, at altitudes ranging from $850-2200 \mathrm{~m}$. They were brought to the laboratory and raised, according to standard methods, in plastic boxes at temperatures of $\pm 27^{\circ} \mathrm{C}$, with food and water provided once every week. Courtship and mating behavior of two females was observed. They gave birth to 14 and 15 offspring, respectively, of which a few were isolated and reached maturity. Three isolated females were maintained in rooms were the temperature averaged $\pm 18^{\circ} \mathrm{C}$. Food and water were provided only once every 21 days. They gave birth to several broods without being inseminated, suggesting a new example of parthenogenesis in scorpions. Postembryonic development was achieved by most members of the different broods and revealed that all the broods were composed of males and females, suggesting the first case of deutherotokous (male and female brood) parthenogenesis. Parthenogenetic broods were smaller - 1 to 8 offspring - than sexual broods (Figure 25). Moreover, the developmental periods observed in the parthenogenetic broods were shorter than those observed in other species of Tityus studied (21).

'Pico da Neblina' is located in North-Western Amazonia. It is characterized by considerable diversity of habitats resulting from an orographic zonation of vegetation 
and a mosaic pattern of soil types, ranging from 100 to near 3000 meters above sea level. Lowland primary tropical rainforest is the predominant ecosystem (2). The vegetation is luxurious from 100 to up to 1000 meters; it is more open and composed of small trees from 1000 to 1700 meters. From 1800 meters up to the top of the mountain, the vegetation is very low and the climate much drier. In fact, precipitation is important up to 1000 meters, and the climate is very wet. Temperatures in the wet zones range from 28 to $34^{\circ} \mathrm{C}$ during the day and from 20 to $24^{\circ} \mathrm{C}$ at night. At altitudes above 2000 meters, conditions are much drier and stressful. Rain is sparse and average temperatures fluctuate from $22^{\circ} \mathrm{C}$ during the day to $12^{\circ} \mathrm{C}$ at night.

The new species of Tityus was collected in sites ranging from the mesic zones to the drier zones. When the abiotic conditions of more xeric zones are reproduced in the laboratory, parthenogenesis appears to be the most advantageous mode of reproduction. This seems to be in accordance with Vandel's (54) rule of geographic parthenogenesis. Several aspects of the reproductive biology of this species are still under investigation. It will be described, and its complete life cycle outlined later.

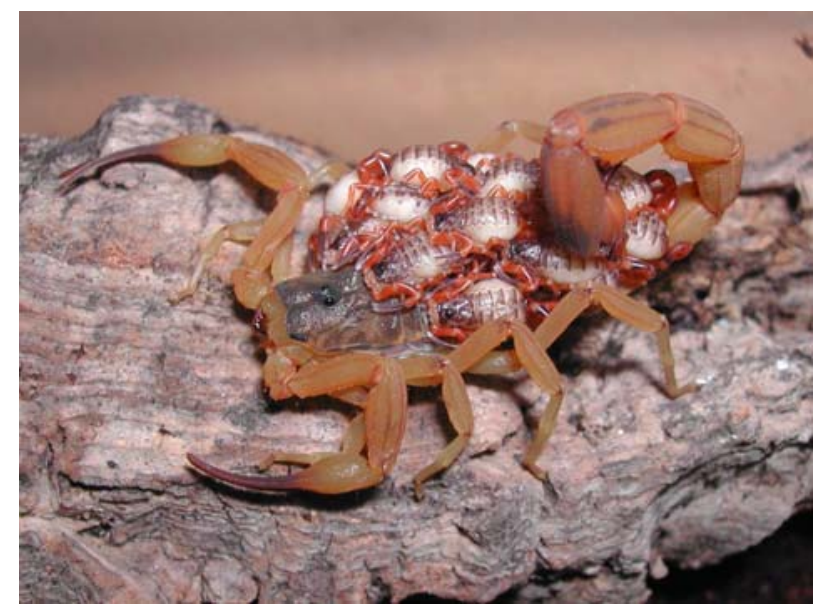

Figure 1. Parthenogenetic female of Tityus serrulatus with brood. 
W. R. Lourenço PARTHENOGENESIS IN SCORPIONS: SOME HISTORY - NEW DATA. J. Venom. Anim. Toxins incl. Trop. Dis., 2008, 14, 1, p. 30

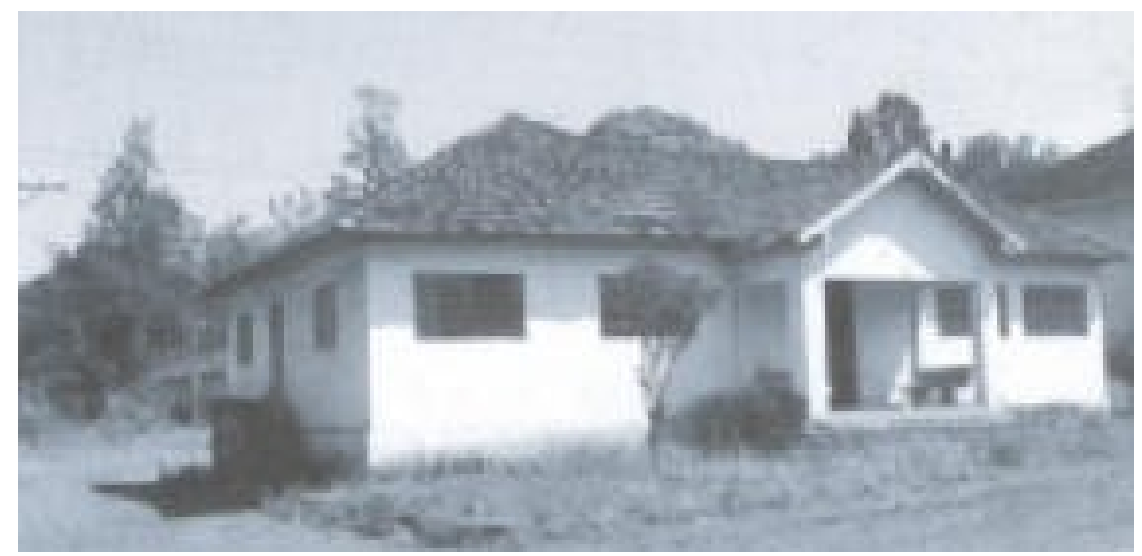

Figure 2. Building of the Department of Zoology in the University of Rio Claro in the late 1960's, where F. Matthiesen did his work.

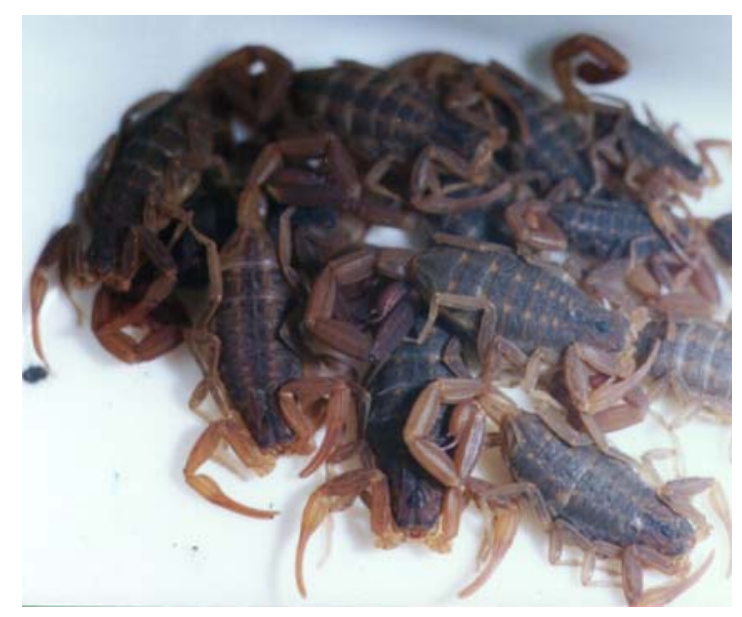

Figure 3. Tityus uruguayensis in a gregarious position.

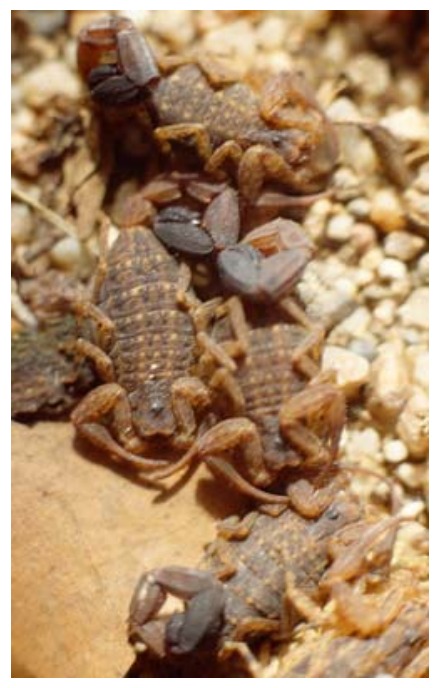

Figure 4. Tityus columbianus in a gregarious position. 
W. R. Lourenço PARTHENOGENESIS IN SCORPIONS: SOME HISTORY - NEW DATA. J. Venom. Anim. Toxins incl. Trop. Dis., 2008, 14, 1, p. 31

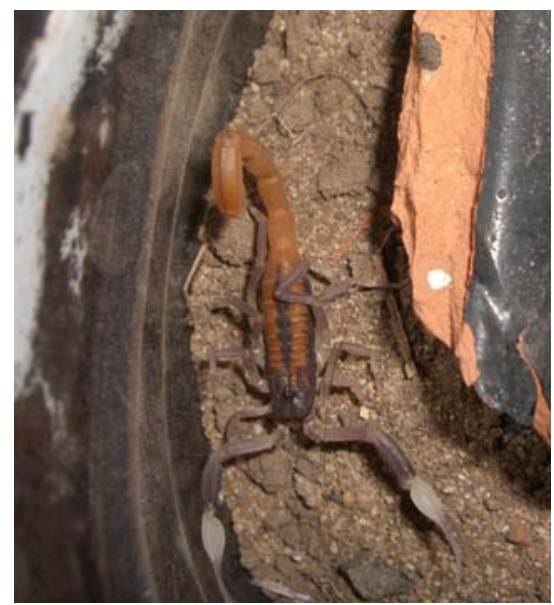

Figure 5. Male of Tityus trivittatus.

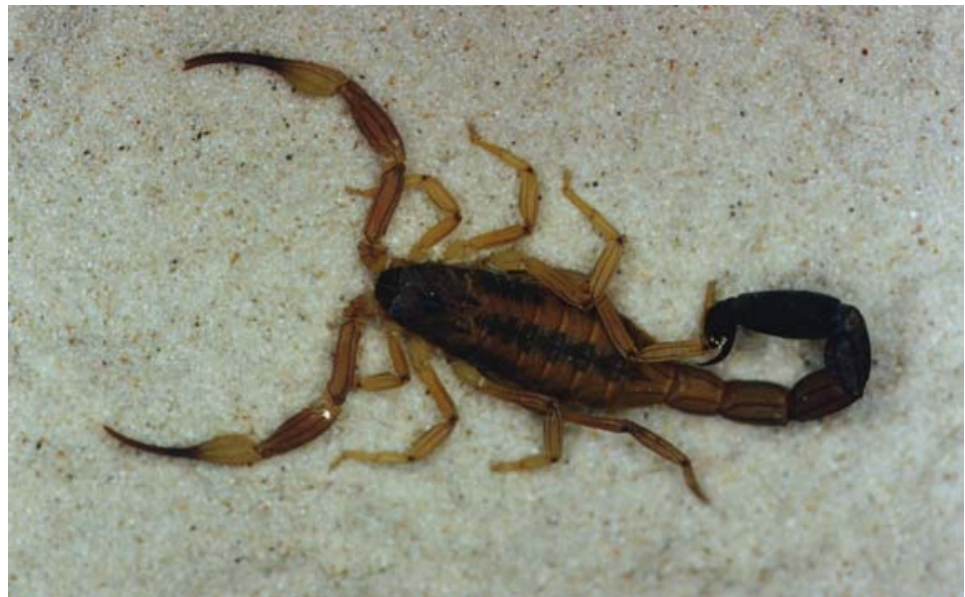

Figure 6. Female of Tityus trivittatus.

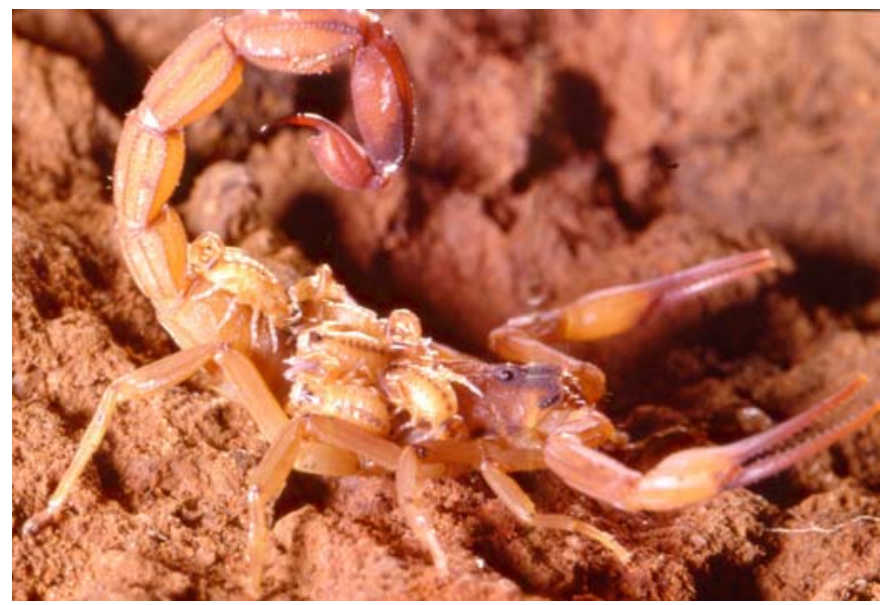

Figure 7. Parthenogenetic female of Tityus stigmurus with brood. 
W. R. Lourenço PARTHENOGENESIS IN SCORPIONS: SOME HISTORY - NEW DATA. J. Venom. Anim. Toxins incl. Trop. Dis., 2008, 14, 1, p. 32

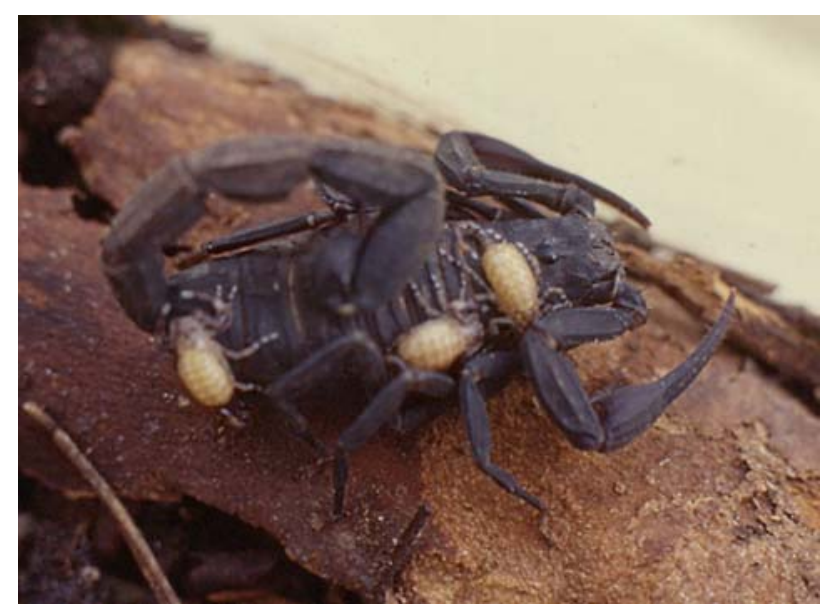

Figure 8. Birth behavior in parthenogenetic female of Tityus metuendus.

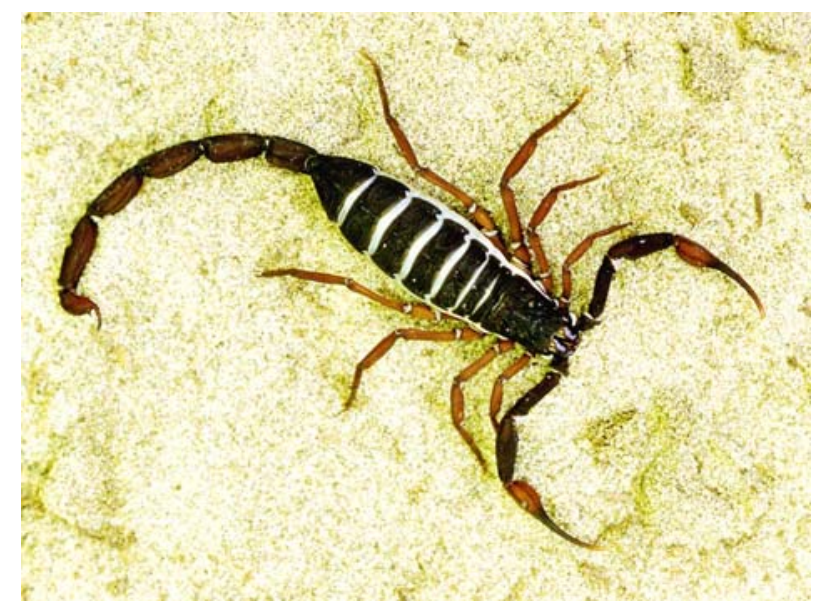

Figure 9. Female of Centruroides gracilis.

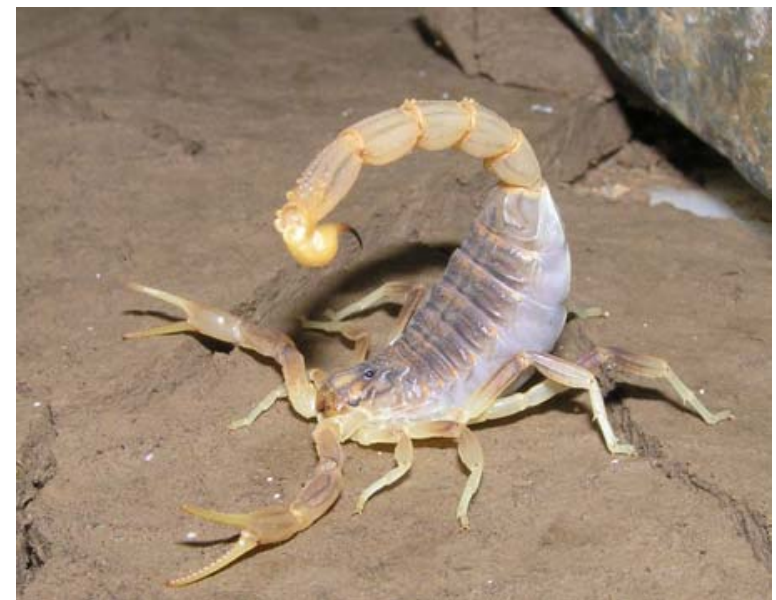

Figure 10. Female of Hottentotta hottentotta. 
W. R. Lourenço PARTHENOGENESIS IN SCORPIONS: SOME HISTORY - NEW DATA. J. Venom. Anim. Toxins incl. Trop. Dis., 2008, 14, 1, p. 33

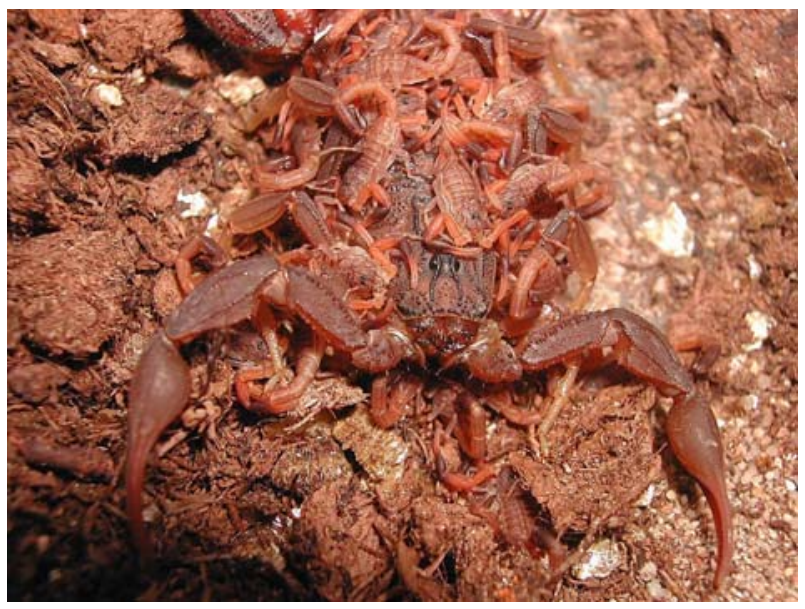

Figure 11. Parthenogenetic female of Hottentotta caboverdensis with brood.

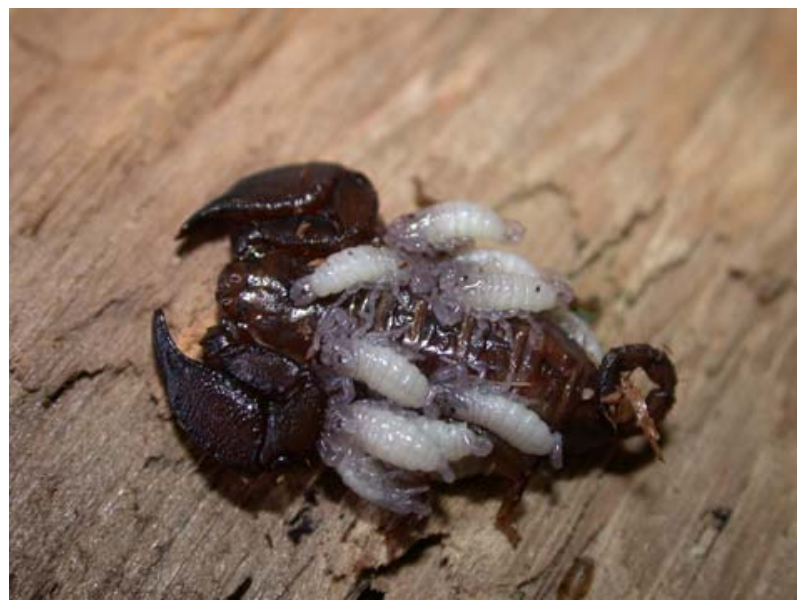

Figure 12. Female of Liocheles australasiae with brood. 


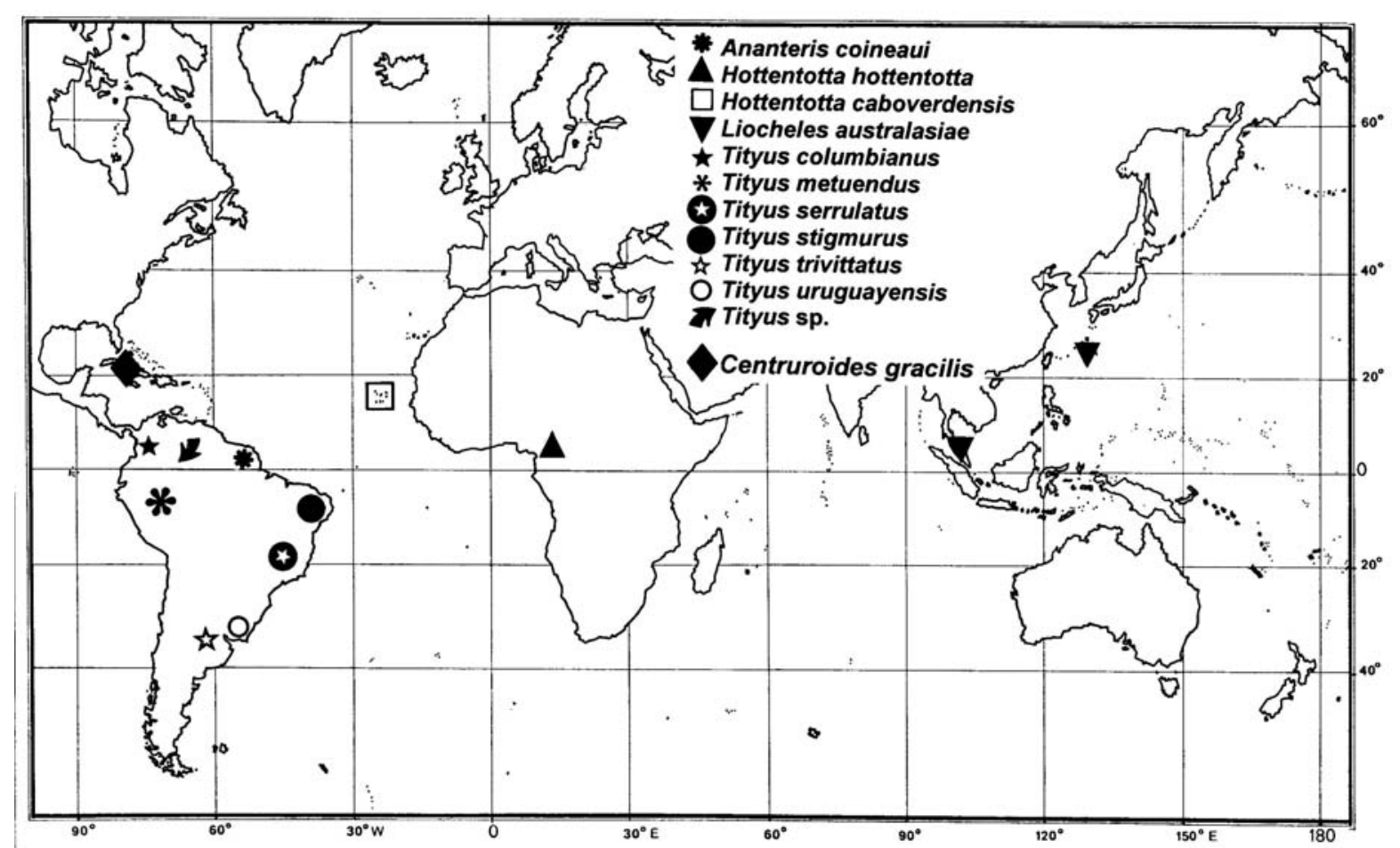

Figure 13. Map showing the distribution of parthenogenetic populations of scorpions.

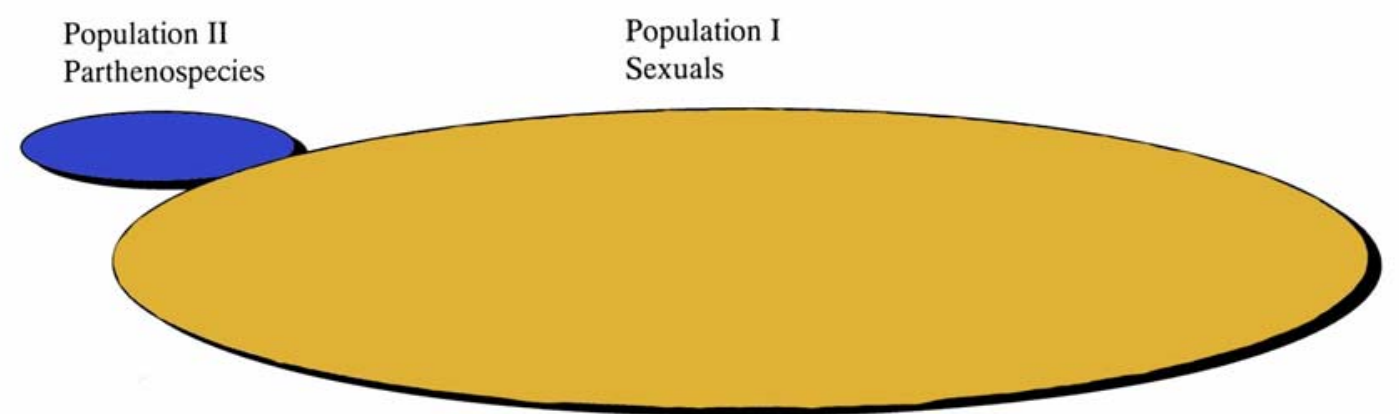

Figure 14. Schematic representation of the distribution of sexual and parthenogenetic populations (geographic parthenogenesis). 


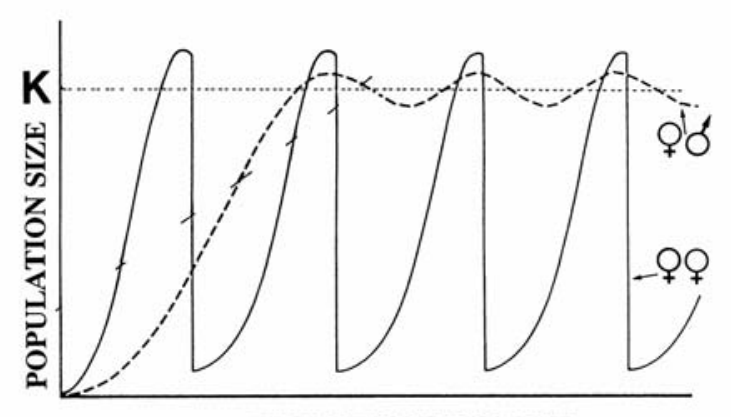

EVOLUTIONARY TIME

Figure 15. Theoretical curves representing the difference between sexual (dotted line) and parthenogenetic (solid line) population fluctuations in nature. The beginning of each curve, up to line $\mathrm{K}$ (carrying capacity), represents the growth rate during the invasion of new habitats. Thereafter, sexual populations fluctuate close to $\mathrm{K}$, whereas the parthenogenetic populations fluctuate radically, overshooting $K$ between catastrophes due to a high rate of increase, and crashing to a low level during catastrophes (adapted from Cuellar - 6).

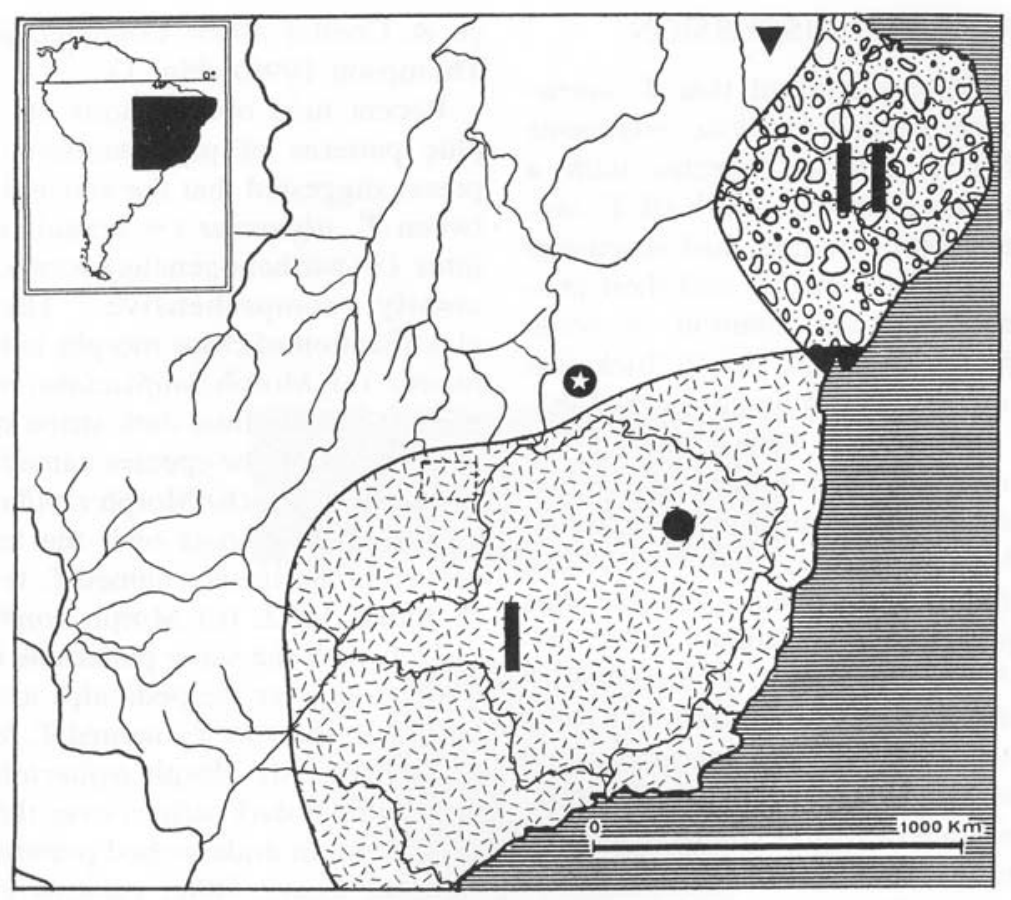

Figure 16. Geographical distribution of Tityus serrulatus (zone I) and possible location of the sexual population in the north of Minas Gerais State (black circle). 
W. R. Lourenço PARTHENOGENESIS IN SCORPIONS: SOME HISTORY - NEW DATA. J. Venom. Anim. Toxins incl. Trop. Dis., 2008, 14, 1, p. 36

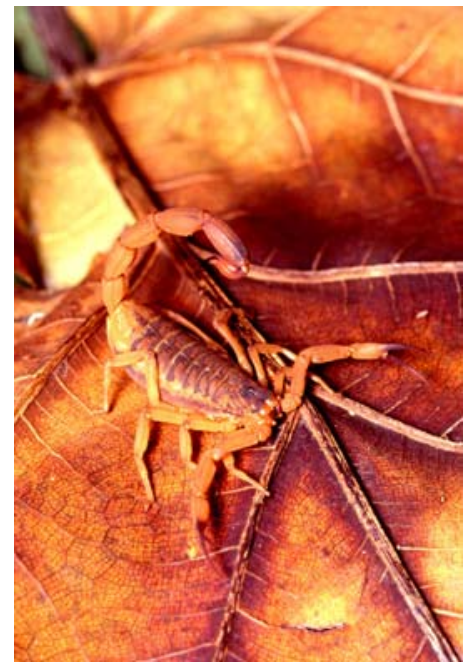

Figure 17. Female of Tityus serrulatus in the wild.

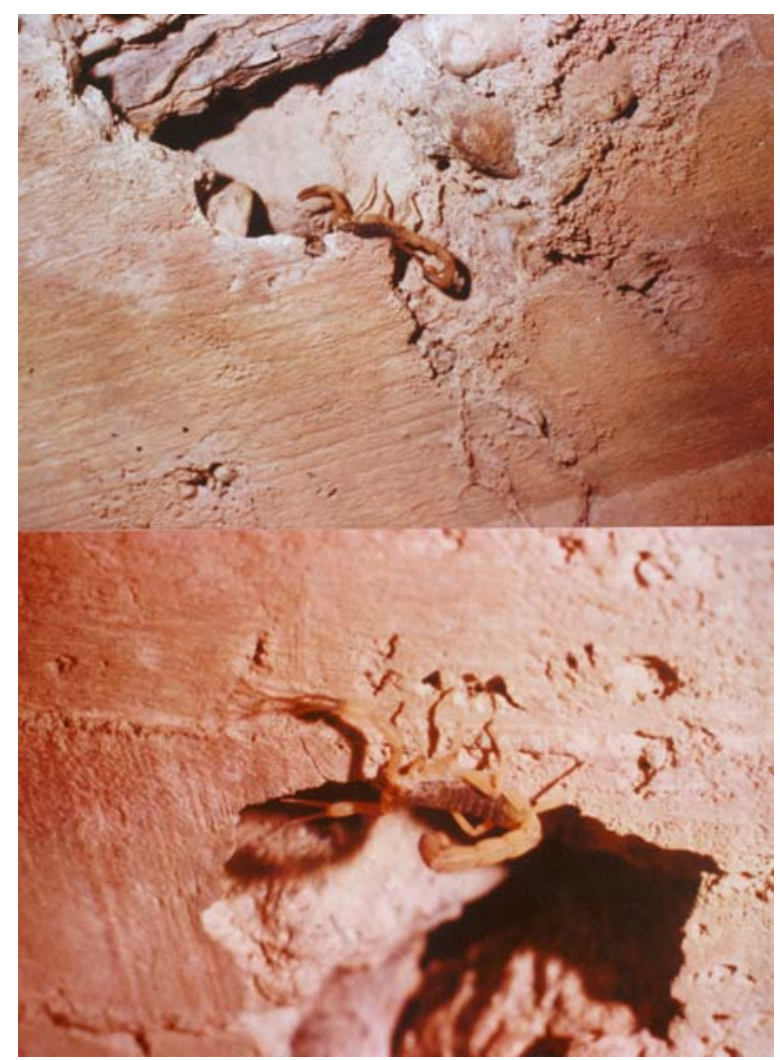

Figure 18. Parthenogenetic female of Tityus serrulatus in the sewer system of Brazilian cities. 
W. R. Lourenço PARTHENOGENESIS IN SCORPIONS: SOME HISTORY - NEW DATA. J. Venom. Anim. Toxins incl. Trop. Dis., 2008, 14, 1, p. 37

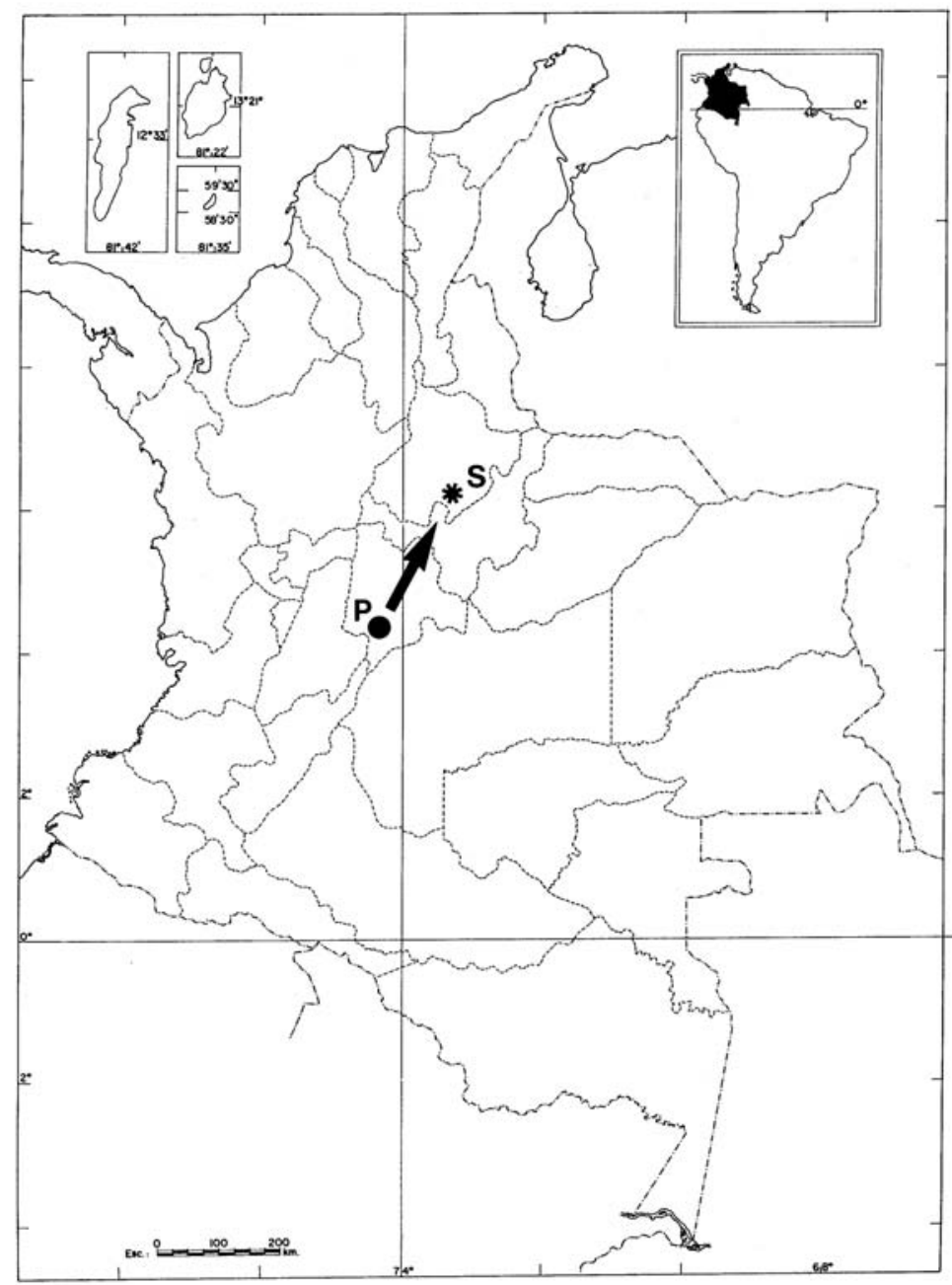

Figure 19. Location of Mosquera and Iza in Colombia where parthenogenetic $(P)$ and sexual (S) populations of Tityus columbianus are distributed.

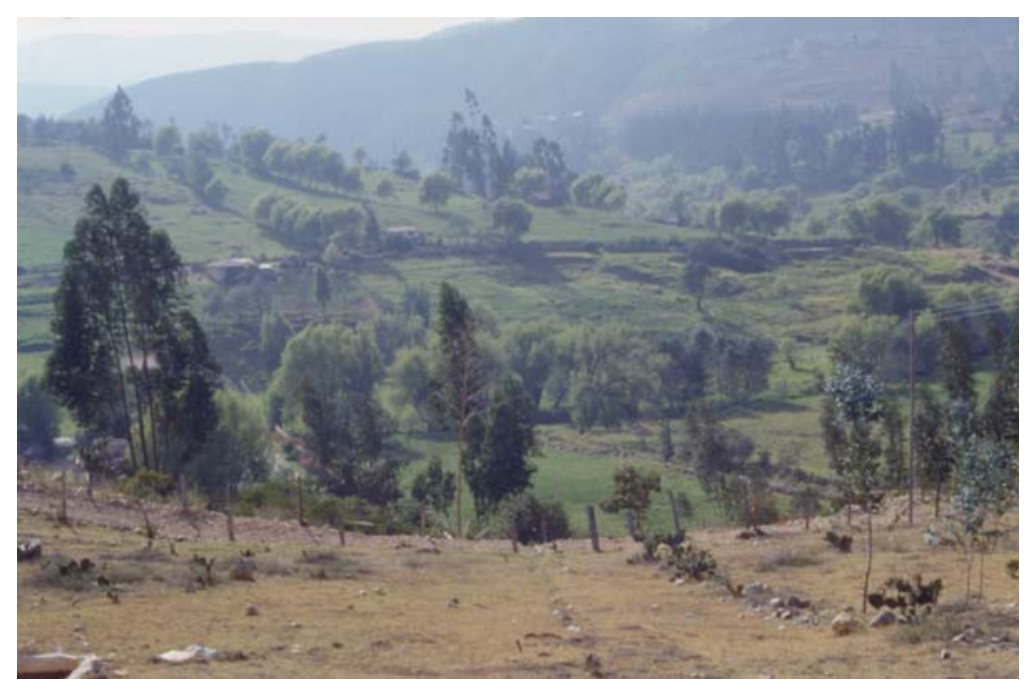

Figure 20. The moist valley at Iza. 
W. R. Lourenço PARTHENOGENESIS IN SCORPIONS: SOME HISTORY - NEW DATA. J. Venom. Anim. Toxins incl. Trop. Dis., 2008, 14, 1, p. 38

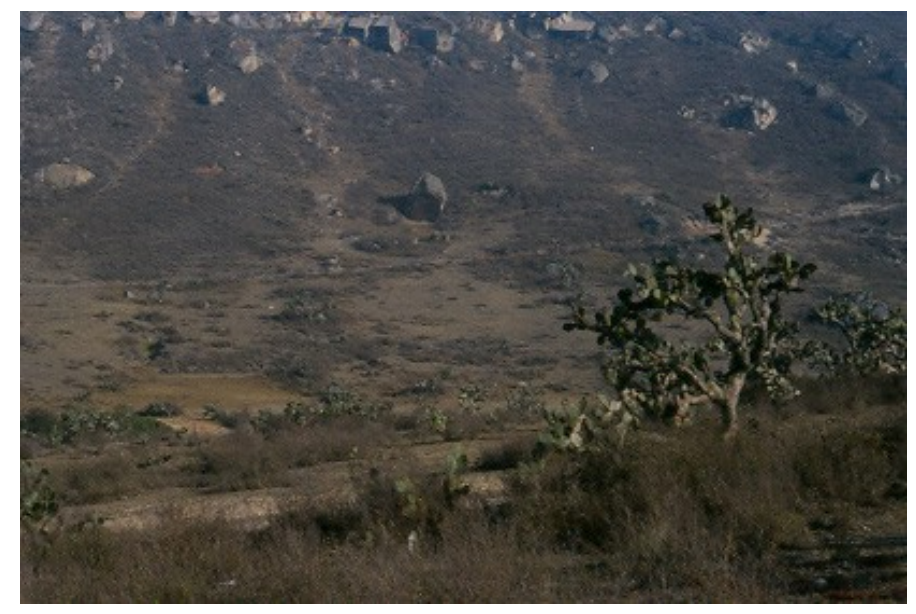

Figure 21. The dry canyon at Mosquera.

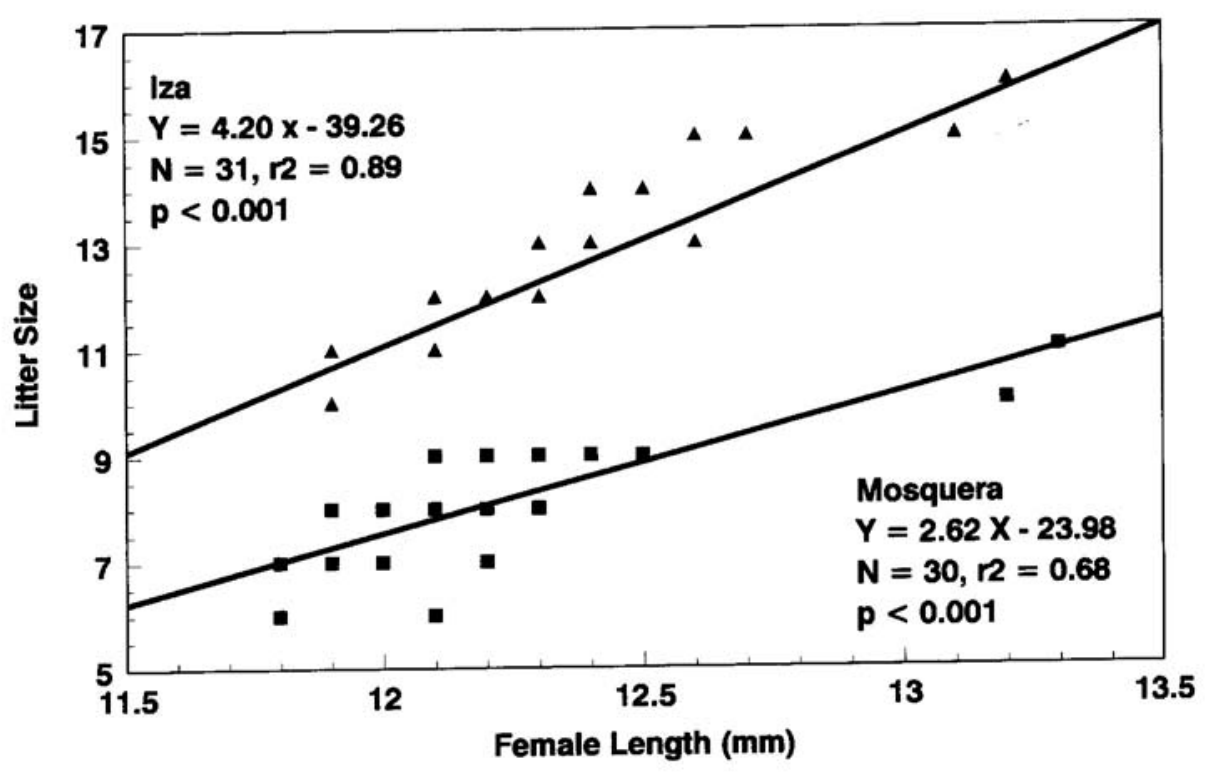

Figure 22. Correlation between clutch size and female body size for Iza and Mosquera populations of Tityus columbianus (from Lourenço et al., 29).

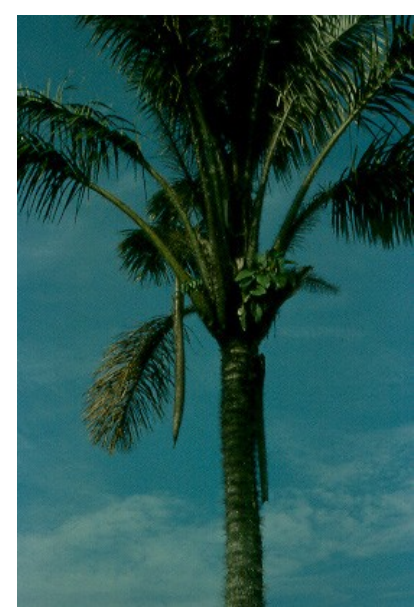

Figure 23. Palm tree, Astrocaryum chambira, in Peruvian Amazon, where parthenogenetic female of Tityus metuendus was collected. 


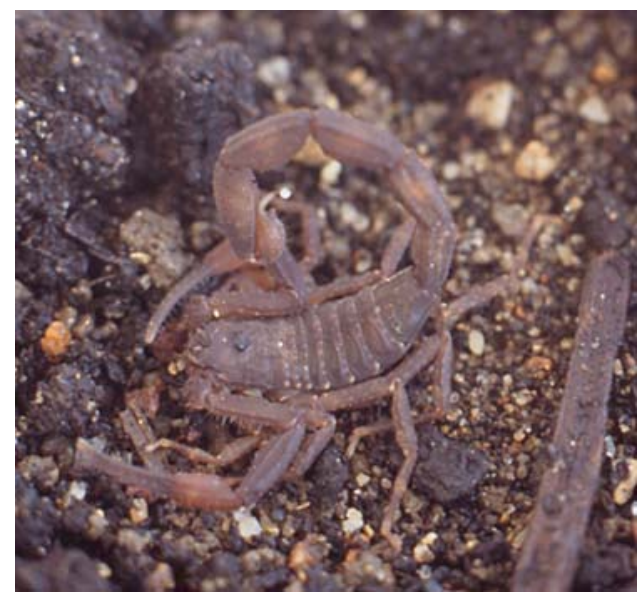

Figure 24. Fifth instar adult male of Tityus metuendus issued from parthenogenetic reproduction.

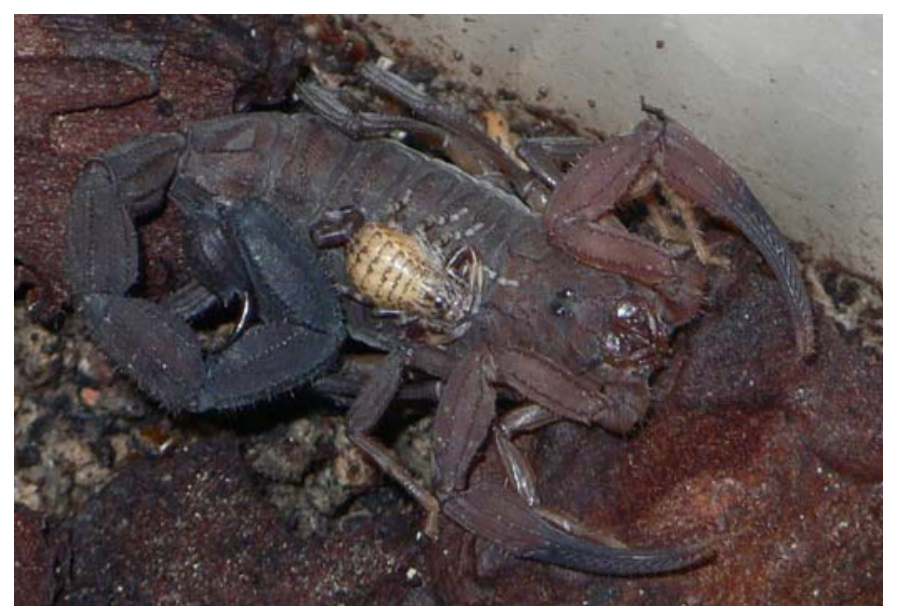

Figure 25. Female of Tityus sp. from 'Pico da Neblina' (Brazil / Venezuela) with parthenogenetic brood composed of a single offspring.

\section{ACKNOWLEDGEMENTS}

I am very grateful to Professor John L. Cloudsley-Thompson, London, for reviewing the manuscript. My thanks go also to several colleagues who supplied me with photos used in this article: Eric Ythier, Jan Ove Rein, Elisangela A. da Silva, and Benedito Barraviera. 


\section{REFERENCES}

1 BELL G. The Masterpiece of Nature. Berkeley: University of California Press, 1982.

2 BOUBLI JP. Lowland floristic assessment of Pico da Neblina National Park, Brazil. Vegetatio, 2002, 160, 149-67.

3 BULL JJ. The evolution of sex chromosomes and sex determining mechanisms. California: Benjamin \& Cummings, 1983. 316p.

4 CAMACHO JP. Female-biased sex ratio in spiders caused by parthenogenesis. Hereditas, 1994, 120, 183-5.

5 CHARNOV EL. The Theory of Sex Allocation: monographs in Population Biology. Princeton: Princeton University Press, 1982. 355p.

6 CUELLAR O. Animal parthenogenesis. Science, 1977, 197, 837-43.

7 CUELLAR O. The evolution of parthenogenesis: a historical perspective. In: MOENS PB. Ed. Meiosis. New York: Academic Press Inc., 1987: 43-104.

8 CUELLAR O. Biogeography of parthenogenetic animals. Biogeographica, 1994, 70, 1-13.

9 EDWARDS RL., EDWARDS EH., EDWARDS AD. Observations of Theotima minutissimus (Araneae, Ochyroceratidae), a parthenogenetic spider. J. Arachnol., 2003, 31, 274-7.

10 FOELIX RF. Biology of Spiders. 2.ed. Oxford: Oxford University Press, 1996. $384 p$.

11 GHISELIN MT. The economy of nature and the evolution of sex. Berkeley: University of California Press, 1974. 346p.

12 GLESENER RR., TILMAN D. Sexuality and the components of environmental uncertainty: clues from geographic parthenogenesis in terrestrial animals. Am. Nat., 1978, 112, 659-73.

13 KAHN F. Les palmiers de l'Eldorado. Paris: ORSTOM, 1997. 252p.

14 LAKE DC. Possible parthenogenesis in the Huntsman spider Isopoda insignis (Araneae, Sparassidae). J. Arachnol., 1986, 14, 129.

15 LELOUP Y. Les villes du Minas Gerais. Mem. Inst. Haut. Etud. Am. Lat., 1970, 25, 1-301.

16 LOKKI J., SAURA A., LANKIN P., SUOMALAINEN E. Genetic polymorphism and evolution in parthenogenetic animals. VI. Diploid and triploid Polydrosus mollis (Coleoptera: Curculionidae). Hereditas, 1976, 82, 209-16. 
17 LOURENÇO WR. La biologie sexuelle et développement postembryonnaire du scorpion Buthidae: Tityus trivittatus fasciolatus Pessôa, 1935. Rev. Nordest. Biol., 1979, 2, 49-96.

18 LOURENÇO WR. Sur la systématique des Scorpions appartenant au complexe Tityus stigmurus (Thorell, 1877) (Buthidae). Rev. Bras. Biol., 1981, 41, 351-62.

19 LOURENÇO WR. Contribution à la connaissance du Scorpion amazonien Tityus metuendus Pocock, 1897 (Buthidae). Stud. Neotrop. Fauna Environ., 1983, 18, 18593.

20 LOURENÇO WR. Parthenogenesis in the scorpion Tityus columbianus (Thorell) (Scorpiones: Buthidae). Bull. Br. Arachnol. Soc., 1991, 8, 274-6.

21 LOURENÇO WR. Reproduction in scorpions, with special reference to parthenogenesis. In: TOFT S., SCHARFF N. Eds. European Arachnology 2000. Aarhus: Aarhus University Press, 2002: 71-85.

22 LOURENÇO WR., CLOUDSLEY-THOMPSON JL. Effects of human activities on the environment and the distribution of dangerous species of scorpions. In: BON C., GOYFFON M. Eds. Envenomings and their treatments. Lyon: Editions Fondation M. Mérieux, 1996: 49-60.

23 LOURENÇO WR., CLOUDSLEY-THOMPSON JL. Discovery of a sexual population of Tityus serrulatus, one of the morphs within the complex Tityus stigmurus (Scorpiones, Buthidae). J. Arachnol., 1999, 27, 154-8.

24 LOURENÇO WR., CLOUDSLEY-THOMPSON JL., CUELLAR O. A review of parthenogenesis in scorpions with a description postembryonic development in Tityus metuendus (Scorpiones, Buthidae) from Western Amazonia. Zoologischer Anzeiger, 2000, 239, 267-76.

25 LOURENÇO WR., CLOUDSLEY-THOMPSON JL., CUELLAR O., VON EICKSTEDT VRD., BARRAVIERA B., KNOX MB. The evolution of scorpionism in Brazil in recent years. J. Venom. Anim. Toxins., 1996, 2, 121-34.

26 LOURENÇO WR., CUELLAR O. Notes on the geography of parthenogenetic scorpions. Biogeographica, 1994, 70, 19-23.

27 LOURENÇO WR., CUELLAR O. Scorpions, scorpionism, life history strategies and parthenogenesis. J. Venom. Anim. Toxins., 1995, 1, 50-64.

28 LOURENÇO WR., CUELLAR O. A new all-female scorpion and the first probable case of arrhenotoky in scorpions. J. Arachnol., 1999, 27, 149-53. 
29 LOURENÇO WR., CUELLAR O., MENDEZ DE LA CRUZ FR. Variation of reproductive effort between parthenogenetic and sexual populations of the scorpion Tityus columbianus. J. Biogeogr., 1996, 23, 681-6.

30 LOURENÇO WR., KNOX MB., YOSHIZAWA MAC. L'invasion d'une communauté a le stade initial d'une succession secondaire par une espèce parthénogénétique de scorpion. Biogeographica, 1994, 70, 77-91.

31 LOURENÇO WR., VON EICKSTEDT VRD. Escorpiões de importância médica. In: CARDOSO JL., SIQUEIRA-FRANÇA FO., WEN FH., SANT'ANA MÁLAQUE CM., HADDAD JR V. Eds. Animais Peçonhentos no Brasil. Biologia, Clínica e Terapêutica dos Acidentes. São Paulo: Sarvier-FAPESP, 2003: 182-97.

32 LOURENÇO WR., YTHIER E., CLOUDSLEY-THOMPSON JL. Parthenogenesis in Hottentotta caboverdensis Lourenço \& Ythier, 2006 (Scorpiones, Buthidae) from the Cape Verde islands. Bol. S.E.A., 2007, 41, 193-196.

33 MAGALHÃES O. Escorpionismo. Bras. Med., 1953, 18/25,19-23.

34 MATTHIESEN FA. Parthenogenesis in scorpions. Evolution, 1962, 16, 255-6.

35 MAURANO HR. O escorpionismo. Rio de Janeiro: Faculdade de Medicina do Rio de Janeiro, 1915. [PhD Thesis].

36 MAYNARD SMITH J. The evolution of sex. Cambridge: Cambridge University Press, 1978.

37 MAYNARD SMITH J. Evolutionary Genetics. Oxford: Oxford University Press, 1989.

38 MAYR E. Animal species and evolution. Cambridge: Belknap Mass, 1963.

39 MELLO-CAMPOS O. Os escorpiões brasileiros. Mem. Inst. Oswaldo Cruz, 1924, 17, 237-363.

40 MELLO-LEITÃo C. Revisão do gênero Tityus. Physis, 1939, 17, 57-76.

41 MULLER HJ. Some genetic aspects of sex. Am. Nat., 1932, 66, 118-38.

42 NAGELKERKE CJ., SABELIS MW. Precise sex-ratio control in the pseudoarrhenotokous phytoseiid mite Typhlodromus occidentalis Nesbitt. In: SCHUSTER R., MURPHY PW. Eds. The Acari: reproduction, development and life-history strategies. London: Chapman \& Hall, 1991: 193-207.

43 NORTON RA., PALMER SC. The distribution, mechanisms and evolutionary significance of parthenogenesis in oribatid mites. In: SCHUSTER R., MURPHY PW. Eds. The Acari: reproduction, development and life-history strategies. London: Chapman \& Hall, 1991: 107-36. 
44 PALMER SC., NORTON RA. Taxonomic, geographic and seasonal distribution of thelytokous parthenogenesis in the Desmonomata (Acari: Oribatida). Exp. Appl. Acarol., 1991,12, 67-81.

45 PESSÔA SB. Nota sobre alguns escorpiões do gênero Tityus e Bothriurus. An. Paulista Med. Cir., 1935, 29, 429-36.

46 SAN MARTIN P., GAMBARDELLA LA. Nueva comprobación de la partenogenesis en Tityus serrulatus (Lutz \& Mello-Campos, 1922) (Scorpionida, Buthidae). Rev. Soc. Ent. Arg., 1966, 28, 79-84.

47 SUOMALEINEN E. Parthenogenesis in animals. Advanc. Genetics, 1950, 3, 193253.

48 SUOMALEINEN E. Evolution in parthenogenetic Curculionidae. Evol. Biol., 1969, 3, 261-96.

49 TABERLY G. Recherches sur la parthénogenèse thélytoque de deux espèces d'Acariens Oribates: Trhypochthonius tectorum (Berlese) et Platynothrus peltifer (Koch). J. Acarol., 1987, 28, 187-98.

50 TAYLOR PD., SAUER A. The selective advantage of sex-ratio homeostasis. Am. Nat., 1980, 116, 305-10.

51 TERUEL R. Primer registro de partenogénesis en Centruroides gracilis (Latreille, 1804) (Scorpiones: Buthidae). Rev. Ibér. Aracnol., 2004, 9, 141-2.

52 TOSCANO-GADEA C. Confirmation of parthenogenesis in Tityus trivittatus Kraepelin, 1898 (Scorpiones, Buthidae). J. Arachnol., 2005, 33, 866-9.

53 TSURUSAKI N. Parthenogenesis and geographic variation of sex ratio in two species of Leiobunum (Arachnida, Opiliones). Zool. Sci., 1986, 3, 517-32.

54 VANDEL A. La parthénogenèse géographique: contribution à l'étude biologique et cytologique de la parthénogenèse naturelle. Bull. Biol. France Belg., 1928, 62, 164281.

55 VAN VALEN L. A new evolutionary law. Evol. Theory, 1973, 1, 1-30.

56 VELLARD J. Scorpions. In: Mission scientifique au Goyaz et au Rio Araguaya. Mém. Soc. Zool. France, 1932, 29, 539-56.

57 VON EICKSTEDT VRD. Escorpionismo por Tityus stigmurus no Nordeste do Brasil (Scorpiones; Buthidae). Mem. Inst. Butantan, 1983, 47/48, 133-7.

58 WAAGE JK. Family planning in parasitoids: adaptive patterns of progeny and sex allocation. In: WAAGE JK., GREATHEAD D. Eds. Insect Parasitoids. London: Academic Press, 1986: 63-95. 
W. R. Lourenço PARTHENOGENESIS IN SCORPIONS: SOME HISTORY - NEW DATA. J. Venom. Anim. Toxins incl. Trop. Dis., 2008, 14, 1, p. 44

59 WHITE MJD. Animal Cytology and Evolution. Cambridge: Cambridge University Press, 1954. 454p.

60 WHITE MJD. Animal Cytology and Evolution. New York: Cambridge University Press, 1973. 931p.

61 WILLIAMS GC. Sex and evolution. Princeton: Princeton University Press, 1975.

62 YAMAZAKI K., MAKIOKA T. Parthenogenesis through five generations in the scorpion Liocheles australasiae (Fabricius, 1775) (Scorpiones, Ischnuridae). J. Arachnol., 2005, 32, 852-6. 